\title{
Isolation of bovine plasma albumin by liquid chromatography and its polymerization for use in immunohematology
}

K. Tanaka, E. Sawatani, E.M. Shigueoka, G.A. Dias,

H.C. Nakao and F. Arashiro

\author{
Divisão de Pesquisa e Desenvolvimento Industrial \\ Fundação Pró-Sangue Hemocentro de São Paulo, \\ São Paulo, SP, Brasil
}

\section{Correspondence \\ K. Tanaka \\ Divisão de Pesquisa e \\ Desenvolvimento Industrial \\ Fundação Pró-Sangue Hemocentro \\ de São Paulo \\ Av. Enéas C. Aguiar, 155, 1ํo andar \\ 05403-000 São Paulo, SP \\ Brasil \\ E-mail: tanaka.k@bol.com.br}

Publication supported by FAPESP.

Received 0 ctober 23, 2000

Accepted May 29, 2001

\section{Abstract}

The aim of the method described here is to remove hemoglobin, the major contaminant in the bovine plasma obtained from slaughterhouses, by adding a mixture of $19 \%$ cold ethanol and $0.6 \%$ chloroform, followed by fibrinogen and globulin precipitation by the Cohn method and nonspecific hemagglutinin by thermocoagulation. The experimental volume of bovine plasma was $2,000 \mathrm{ml}$ per batch. Final purification was performed by liquid chromatography using the ionexchange gel DEAE-Sepharose FF. The bovine albumin thus obtained presented $\geq 99 \%$ purity, a yield of $25.0 \pm 1.2 \mathrm{~g} / \mathrm{l}$ plasma and $>71.5 \%$ recovery. $\mathrm{N}$-acetyl-DL-tryptophan $(0.04 \mathrm{mmol} / \mathrm{g}$ protein $)$ and sodium caprylate $(0.04 \mathrm{mmol} / \mathrm{g}$ protein $)$ were used as stabilizers and the final concentration of albumin was adjusted to $22.0 \%$ (w/v), $\mathrm{pH} 7.2$ to 7.3 . Viral inactivation was performed by pasteurization for $10 \mathrm{~h}$ at $60^{\circ} \mathrm{C}$. The bovine albumin for the hemagglutination tests used in immunohematology was submitted to chemical treatment with $0.06 \%(\mathrm{w} / \mathrm{v})$ glutaraldehyde and $0.1 \%(\mathrm{w} / \mathrm{v})$ formaldehyde at $37^{\circ} \mathrm{C}$ for $12 \mathrm{~h}$ to obtain polymerization. A change in molecular distribution was observed after this treatment, with average contents of $56.0 \%$ monomers, $23.6 \%$ dimers, $12.2 \%$ trimers and $8.2 \%$ polymers. The tests performed demonstrated that this polymerized albumin enhances the agglutination of Rho(D)-positive red cells by anti-Rho(D) serum, permitting and improving visualization of the results.

\section{Introduction}

Bovine albumin is very similar to human albumin in terms of structure and physicochemical properties. Its molecular weight is 66,300 to 69,000 Dalton, and the molecule consists of a single and quite long, compactly folded polypeptide chain of about 582 amino acid residues in length with an almost
Key words

- Bovine albumin, production

- Bovine albumin, purification

- Bovine albumin, polymerization

- Bovine albumin downstream process 
serum in 1945 and is widely used today. This serum component may influence the hemagglutination reaction, enhancing the erythrocyte agglutination for better visualization and easier reading of the results, based on factors such as zeta potential reduction, increase of the dielectric constant, release of bound water, change of red cell shape, and reduction in ionic strength (4).

In 1969, Jones et al. (5) reported that polymerized bovine albumin was more effective in potentiating direct agglutination, and that potentiation was directly related to the degree of polymer content. This polymerization has been reported to appear in albumin obtained by ethanol fractionation subjected to freeze-drying, heating, etc., but Reckel and Harris (6) showed that chemically polymerized albumin also presents good serological properties enhancing direct agglutination by a covalent link. The most frequently mentioned theory is that of Pollack et al. (7) who proposed that bovine albumin causes red cells to approach one another more closely. Polymerized bovine albumin raises the dielectric constant of the medium, which reduces the zeta potential. In spite of the great technological achievements in the production and purification of human albumin for therapeutic use, there is an enormous gap regarding production and purification of bovine albumin for diagnostic use. Thus, we developed a method to obtain pure albumin for diagnostic use, free of impurities when used as a stabilizer or in in vitro tests, and presenting high-quality performance compared to the international products. Since the bovine plasma obtained from slaughterhouses shows a high degree of hemolysis, with a dark red color, it is necessary first of all to remove hemoglobin with $0.6 \%$ chloroform and $19.0 \%$ cold ethanol $\left(-20^{\circ} \mathrm{C}\right)$ at $\mathrm{pH} 7.2(8,9)$. All the globulins (alpha, beta and gamma) are removed by the method of Cohn et al. (10) and nonspecific hemagglutinin by thermocoagulation (11). Final purification is performed by liquid chro- matography using the anion ion-exchange gel DEAE-Sepharose FF (Pharmacia, Uppsala, Sweden) $(8,12,13)$.

\section{Material and Methods}

Bovine plasma was collected at a slaughterhouse into $10 \%$ sodium citrate. Each experiment was performed with $2,000 \mathrm{ml}$ of this plasma and $\mathrm{pH}$ was adjusted to 7.2 with acetate buffer, $\mathrm{pH} 4.0$ (4 M sodium acetate and $10 \mathrm{M}$ acetic acid). A mixture of ethanol and chloroform was slowly added under homogenization to a final concentration of $19 \%$ ethanol and $0.6 \%$ chloroform. This mixture was kept at $4{ }^{\circ} \mathrm{C}$ and was homogenized for an additional $20 \mathrm{~min}$ in order to obtain complete hemoglobin precipitation. After this step, plasma was kept in a cold room at $-5^{\circ} \mathrm{C}$ overnight for $\gamma$-globulin precipitation. The precipitate consisting of hemoglobin and $\gamma$ globulin was removed by centrifugation at 2,500 $\mathrm{g}$ for $10 \mathrm{~min}$ at $-5^{\circ} \mathrm{C}$ (Sorvall RC-3B plus, Du Pont, Wilmington, DE, USA) and discarded. The $\mathrm{pH}$ of supernatant I (Figure 1) was adjusted to 6.0 with acetate buffer solution, $\mathrm{pH} 4.0$, under homogenization for about $30 \mathrm{~min}$ at $-5^{\circ} \mathrm{C}$ and the preparation was left to stand for $6 \mathrm{~h}$ to precipitate $\alpha$ - and $\beta$ globulin, which were removed by centrifugation as described above and discarded. Supernatant II thus obtained (Figure 1) was submitted to diafiltration with tangential ultrafiltration with a Pellicon cassette system (NMWL PLGC, Millipore, Bedford, MA, USA) to remove ethanol and chloroform. The supernatant was concentrated to $7 \%$ protein and the volume after this step was $1,000 \mathrm{ml} ; \mathrm{pH}$ was adjusted to 6.6 with $0.5 \mathrm{M}$ $\mathrm{NaOH}$ and conductivity was adjusted to 5.0 $\mathrm{mS} / \mathrm{cm}$ with $\mathrm{NaCl}$. Sodium caprylate was then added at the proportion of $0.16 \mathrm{mmol} / \mathrm{g}$ albumin, and ethanol was added to a final concentration of $9 \%(\mathrm{v} / \mathrm{v})$; this preparation was submitted to heat treatment until it reached a temperature of $70^{\circ} \mathrm{C}$ within approximately $1 \mathrm{~h}$ and $30 \mathrm{~min}$. The preparation 
was then cooled to $20^{\circ} \mathrm{C}$, with $\mathrm{pH}$ adjusted to 4.5 with $1.0 \mathrm{M} \mathrm{HCl}$, and kept at $4^{\circ} \mathrm{C}$ overnight to precipitate fatty acids, nonspecific hemagglutinin and residual globulin. The precipitates were removed by centrifugation at $2,500 \mathrm{~g}$ for $10 \mathrm{~min}$ at $4^{\circ} \mathrm{C}$ and discarded. Supernatant III (Figure 1) was clarified with a 60-S deep filter (Zeta plus, Cuno, Meriden, CT, USA) in a cold room at $+4^{\circ} \mathrm{C}$. After filtration, the operating temperature was $22^{\circ} \mathrm{C}$, the filtrate $\mathrm{pH}$ was adjusted to 5.4 with $1.0 \mathrm{M} \mathrm{NaOH}$, and conductivity was adjusted to $1.40 \mathrm{mS} / \mathrm{cm}$ by the addition of deionized water. The filtrate volume, which became $7,000 \mathrm{ml}$ at this step, was reduced to 2,000 $\mathrm{ml}$ with a 10-kDa Pellicon cassette system. The preparation was then applied to an XK50/30 chromatographic column packed with $320 \mathrm{ml}$ of ion-exchange gel, DEAE-Sepharose $\mathrm{FF}$, previously equilibrated with acetate buffer, pH 5.4 (20 mM sodium acetate, 1.40 $\mathrm{mS} / \mathrm{cm}$ conductivity), and processed in 4 cycles with a linear flow of $65 \mathrm{~cm} / \mathrm{h}$.

After sample application, corresponding to the first cycle, the chromatographic column was washed with 2 total gel volumes (TV) of the equilibrating buffer solution to remove proteins not adsorbed on the gel. The adsorbed albumin was eluted with $2 \mathrm{TV}$ of buffer solution, $\mathrm{pH} 4.5$ (2 $\mathrm{mM}$ sodium acetate and $1.75 \mathrm{mS} / \mathrm{cm}$ conductivity), and the other proteins which were still adsorbed on the gel were removed with $2 \mathrm{TV}$ of buffer solution, $\mathrm{pH} 4.0(150 \mathrm{mM}$ sodium acetate and $8.0 \mathrm{mS} / \mathrm{cm}$ conductivity).

For the subsequent cycle, the chromatographic column with the gel was re-equilibrated according to the step described above until the fourth cycle was completed. The gel was regenerated with $2 \mathrm{TV} 0.5 \mathrm{M} \mathrm{NaOH}$ and stored in $10 \mathrm{mM} \mathrm{NaOH}$, as recommended by Pharmacia. The albumin eluted from the DEAE-Sepharose FF gel was concentrated to $25 \%(\mathrm{w} / \mathrm{v})$ and formulated by the addition of $0.04 \mathrm{mmol}$ sodium caprylate/g albumin, $0.04 \mathrm{mmol} \mathrm{N}$-acetyl-DL-tryptophan/g albu$\min (14)$, and $0.1 \%$ sodium azide as stabiliz-

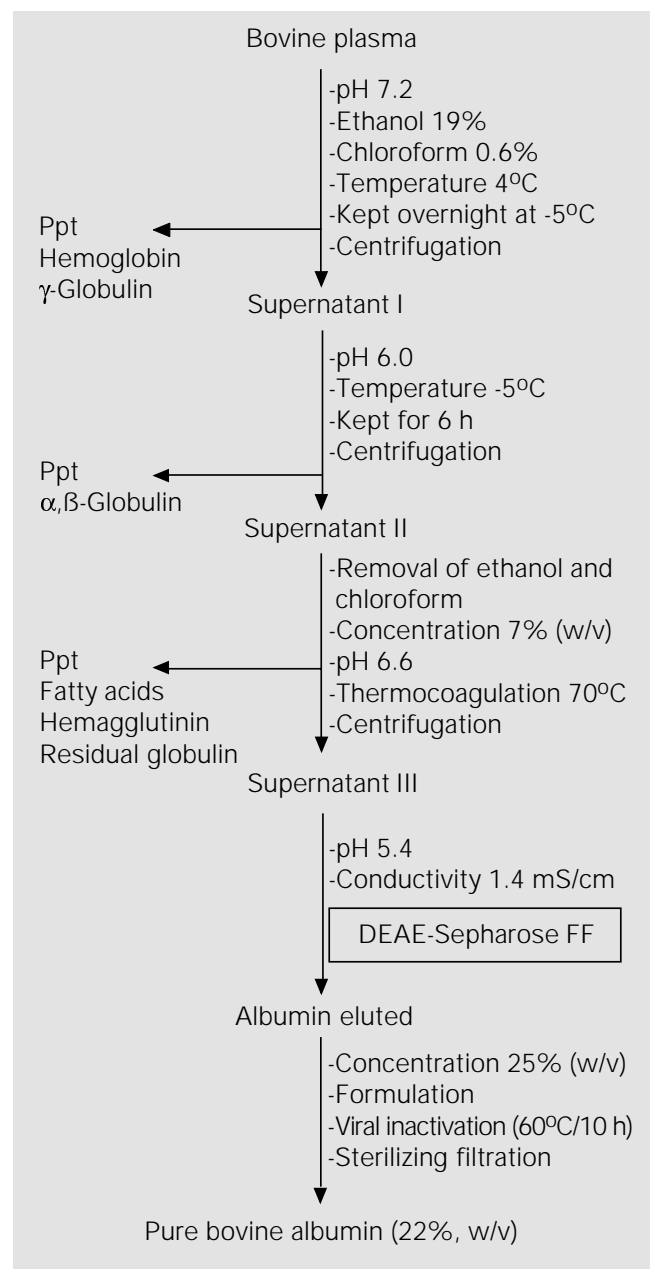

Figure 1 . Schematic presentation of bovine albumin purification. Ppt $=$ precipitate. ers, $\mathrm{pH} 7.2$, with a conductivity of $6.0 \mathrm{mS} /$ $\mathrm{cm}$. After formulation, bulk viral inactivation was performed by pasteurization at $60^{\circ} \mathrm{C}$ for $10 \mathrm{~h}$ and the preparation was filtered through a sterilizing $0.22-\mu \mathrm{m}$ Millipore membrane. The final concentration of bovine albumin after the formulation was adjusted to $22 \%(w / v)$ (Figure 1).

In order to obtain proper polymerization for the hemagglutination tests, prior to the above formulation step part of the $25 \%$ bovine albumin was submitted to a treatment with $0.06 \%$ glutaraldehyde (15) and $0.1 \%$

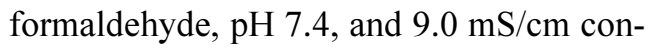
ductivity at $37^{\circ} \mathrm{C}$ for $12 \mathrm{~h}$. After treatment, glutaraldehyde and formaldehyde were removed by diafiltration and the product was concentrated to $25 \%(\mathrm{w} / \mathrm{v})$. The formulation 
Figure 2. Schematic presentation of the polymerization of bovine albumin for use in hemagglutination tests.

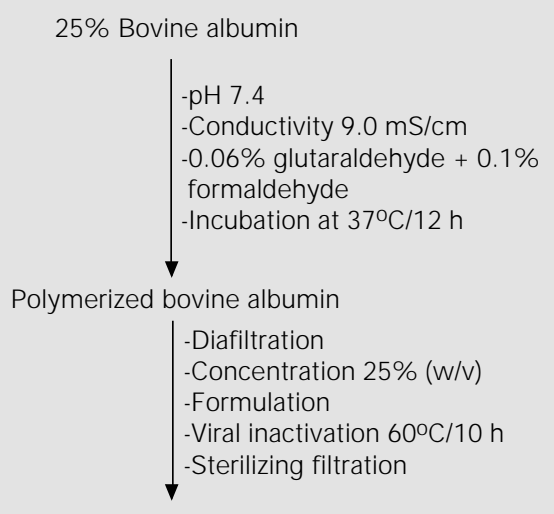

$22 \%$ Polymerized bovine albumin

Table 1. Characteristics of $22 \%(\mathrm{w} / \mathrm{v})$ bovine albumin $(\mathrm{N}=12)$.

\begin{tabular}{lc}
\hline Albumin in the plasma pool & $35.0 \mathrm{~g} / \mathrm{l}$ \\
Yield & $25.0 \pm 1.2 \mathrm{~g} / \mathrm{l}$ plasma \\
Recovery & $71.5 \pm 1.5 \%$ \\
Protein & $22.0 \pm 0.5 \mathrm{~g} / \mathrm{dl}$ \\
Purity (electrophoresis) & $>99.0 \%$ \\
Molecular size distribution & \\
$\quad$ Monomer & $94.4 \pm 1.5 \%$ \\
Dimer & $4.8 \pm 0.05 \%$ \\
Polymer & $0.8 \pm 0.5 \%$ \\
pH & 7.2 to 7.3 \\
Molecular size distribution after treatment with & \\
0.06\% glutaraldehyde and 0.1\% formaldehyde & \\
$\quad$ Monomer & \\
Dimer & $56.0 \pm 1.2 \%$ \\
Trimer & $23.6 \pm 0.6 \%$ \\
Polymer & $12.2 \pm 0.4 \%$ \\
\hline
\end{tabular}

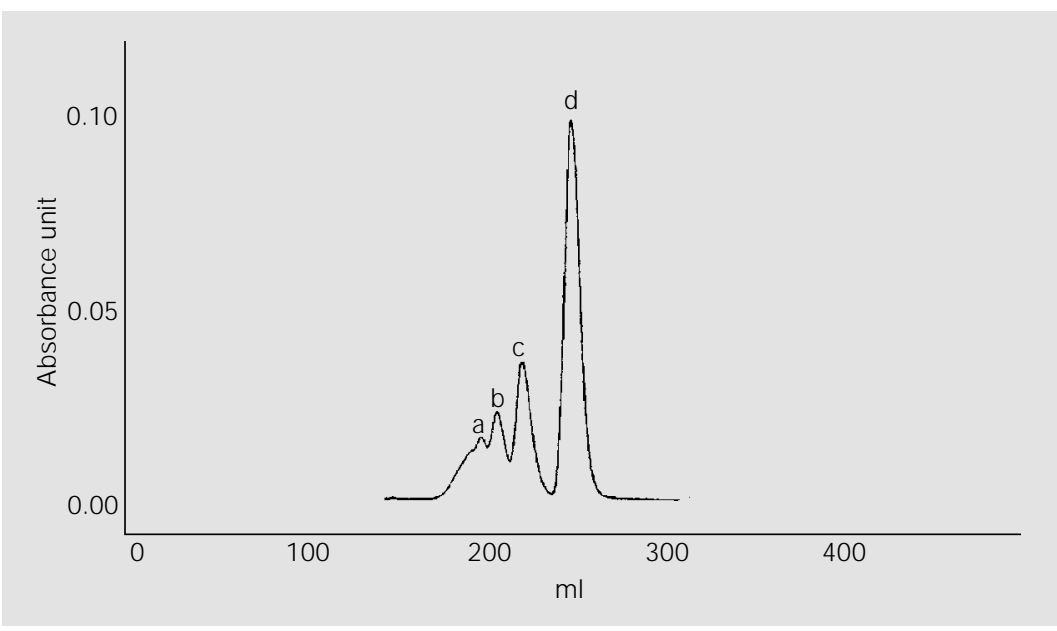

Figure 3. Molecular size distribution of bovine albumin treated with $0.06 \%$ glutaraldehyde/ $0.1 \%$ formaldehyde, determined by gel filtration using two Superdex 200 HR XK-16/60 columns in series. a, polymer; b, trimer; c, dimer; d, monomer. Absorbance at $280 \mathrm{~nm}$. and viral inactivation by pasteurization were performed as already described. The final concentration was adjusted to $22 \%(\mathrm{w} / \mathrm{v})$, $\mathrm{pH} 7.2$ to 7.3 , at $6.0 \mathrm{mS} / \mathrm{cm}$ conductivity (Figure 2). Using the proposed method we produced 20 lots of high-quality bovine albumin.

\section{Analytical methods}

Protein concentration was determined by the biuret method. Albumin purity was determined by electrophoresis on a cellulose acetate membrane and concentration was measured with a Helena H. Junior 24 densitometer (France S.A., Saint Leu la Fôret, France). Immunoelectrophoresis was performed on $1 \%$ agarose gel (16), using the rabbit anti-total bovine plasma serum (Sigma, St. Louis, MO, USA). The relative content of polymers, dimers and monomers was determined on an XK-16/60 column packed with Superdex 200 HR gel (Pharmacia), and native polyacrylamide gel electrophoresis was carried out on 5 to $15 \%$ gradient gels at 110 $\mathrm{V}$ for $1: 20 \mathrm{~h}$ in $25 \mathrm{mM}$ Tris to $0.192 \mathrm{M}$ glycine buffer, $\mathrm{pH}$ 8.3. The plasma hemoglobin-free content was determined by the peroxidase method (17). The hemagglutination enhancement by polymerized bovine albumin was tested by standard antibody screening tests. Anti-Rho(D) antisera were serially diluted and Rho(D)-positive and Rho(D)-negative erythrocytes were used. The color intensity of albumin was determined with a Beckman Du-65 spectrophotometer at $403 \mathrm{~nm}$ absorbance.

The characteristics of $22 \%(\mathrm{w} / \mathrm{v})$ bovine albumin are presented in Table 1 .

\section{Results and Discussion}

The major objective of the present study was to remove hemoglobin and to adapt the process of human albumin fractionation for bovine albumin production, in view of the lack of scientific publications of technolo- 
gies for bovine albumin purification. There are patents held by a few foreign manufacturers.

The state-of-the art technology used for the production of human albumin was modified and adapted to the production of bovine albumin. Since bovine plasma obtained from slaughterhouses contains a significant amount of hemolyzed blood ( $54 \mathrm{mg} / \mathrm{dl}$ free hemoglobin in plasma), the first step was to remove hemoglobin at the very beginning of the process, otherwise it would persist up to the final product, conferring a highly disagreeable dark brown color to it and also possibly precipitating during storage. Another point to consider is the presence of nonspecific hemagglutinin activity in bovine plasma, which shows average titers of 1:1024 for anti-A and 1:256 for anti-B with human red cells A and B, respectively. Therefore, when albumin purification is not well processed, part of these impurities may remain in the final product, interfering with the immunohematological tests. Thus the nonspecific hemagglutinin activity was denatured and

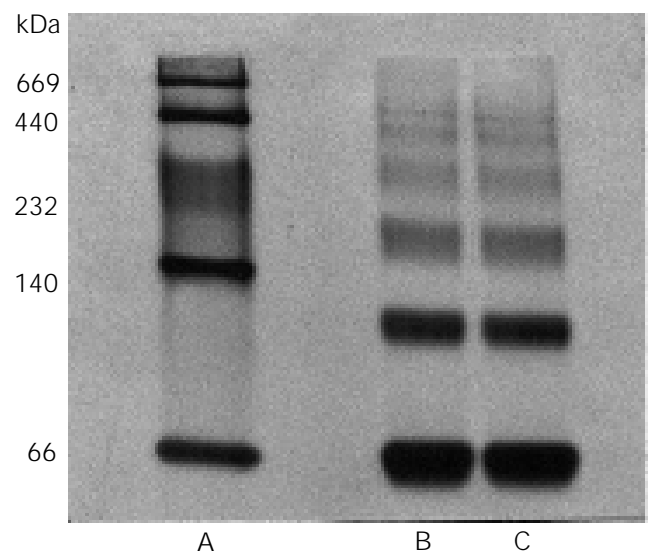

Figure 4. Native polyacylamide gel electrophoresis. Lane A, Native high molecular mass marker (Pharmacia). Lanes B and C, Polymerized bovine albumin.

Table 2. Treatment of bovine albumin with different concentrations of glutaraldehyde/formaldehyde.

\begin{tabular}{lcrcrc}
\hline $\begin{array}{l}\text { Glut/form con- } \\
\text { centration (\%) }\end{array}$ & Monomer (\%) & Dimer (\%) & Trimer (\%) & Polymer (\%) & $\begin{array}{c}\text { Color intensity of albumin } \\
\text { (absorbance at 403 nm) }\end{array}$ \\
\hline $0.00 / 0.00$ & $94.40 \pm 1.53$ & $4.81 \pm 1.05$ & - & $0.78 \pm 0.56$ & 0.279 \\
$0.02 / 0.00$ & $86.25 \pm 1.37$ & $8.46 \pm 0.85$ & $3.86 \pm 0.48$ & $1.44 \pm 0.35$ & 0.440 \\
$0.02 / 0.05$ & $86.27 \pm 1.21$ & $8.70 \pm 0.94$ & $3.55 \pm 0.42$ & $1.48 \pm 0.31$ & 0.280 \\
$0.04 / 0.00$ & $76.90 \pm 1.06$ & $15.87 \pm 0.43$ & $4.86 \pm 0.45$ & $2.38 \pm 0.40$ & 0.973 \\
$0.04 / 0.05$ & $77.50 \pm 1.20$ & $15.85 \pm 1.05$ & $4.60 \pm 0.52$ & $2.05 \pm 0.43$ & 0.683 \\
$0.06 / 0.00$ & $55.42 \pm 1.46$ & $23.54 \pm 0.48$ & $12.27 \pm 0.57$ & $8.29 \pm 0.54$ & 1.350 \\
$0.06 / 0.10$ & $55.96 \pm 1.25$ & $23.63 \pm 0.57$ & $12.21 \pm 0.44$ & $8.23 \pm 0.37$ & 0.285 \\
$0.08 / 0.10$ & $43.83 \pm 1.58$ & $26.99 \pm 0.91$ & $17.10 \pm 0.61$ & $12.13 \pm 0.56$ & 0.685 \\
$0.08 / 0.15$ & $42.49 \pm 1.37$ & $27.24 \pm 0.76$ & $17.85 \pm 0.64$ & $12.42 \pm 0.59$ & 0.288 \\
\hline
\end{tabular}

Intensity of the normal color of albumin: absorbance at $403 \mathrm{~nm}=0.279$. Intensity of the darker color of albumin: absorbance at $403 \mathrm{~nm}=1.350 . \mathrm{N}=5$. glut = glutaraldehyde; form = formaldehyde .

Table 3. Anti-Rho(D) titration using bovine albumin treated with glutaraldehyde/formaldehyde.

\begin{tabular}{lrrrrrrrrrrrc}
\hline & \multicolumn{10}{c}{ Anti-Rho(D) titer } \\
\cline { 2 - 11 } & 1 & $1 / 2$ & $1 / 4$ & $1 / 8$ & $1 / 16$ & $1 / 32$ & $1 / 64$ & $1 / 128$ & $1 / 256$ & $1 / 512$ & Negative control \\
\hline Sigma albumin & 10 & 8 & 5 & 5 & 3 & 3 & - & - & - & - & - \\
Untreated albumin & 10 & 8 & 5 & 5 & 3 & 3 & - & - & - & - & - \\
Albumin with 0.02\% glut & 10 & 8 & 8 & 5 & 3 & 3 & - & - & - & - & - \\
Albumin with 0.04\% glut & 10 & 10 & 8 & 8 & 5 & 5 & 3 & - & - & - & - \\
Albumin with 0.06\% glut & 12 & 10 & 10 & 8 & 8 & 5 & 5 & 3 & - & - & - \\
Albumin with 0.08\% glut & 12 & 12 & 10 & 8 & 8 & 5 & 5 & 3 & 2 & 2 & 2
\end{tabular}

Polymerized bovine albumin at $22 \%$ concentration $(\mathrm{w} / \mathrm{v})$. The intensity of red blood cell agglutination was read by the scoring titration method (19). glut = glutaraldehyde. 
precipitated by heating the product up to $70^{\circ} \mathrm{C}$ with $9 \%$ ethanol (11). It is advisable to use only sodium caprylate as stabilizer for bovine albumin, since its presence at concentration of $\geq 0.08 \mathrm{mmol} / \mathrm{g}$ albumin interferes with the immunohematological tests, impairing the interpretation and detection of erythrocyte antibodies from blood recipients or donors. We used a mixture of sodium caprylate $(0.04 \mathrm{mmol} / \mathrm{g}$ albumin $)$ and $\mathrm{N}$ acetyl-DL-tryptophan $(0.04 \mathrm{mmol} / \mathrm{g}$ albumin $)$ (14) to prevent this problem. With this procedure, bovine albumin showed good stability without interfering with the immunohematological tests. Analysis of the molecular distribution of bovine albumin purified by the described method showed $94.4 \%$ monomers, $4.8 \%$ dimers and $0.8 \%$ polymers, as compared to $90.5 \%$ monomers, $8.8 \%$ dimers and $0.7 \%$ polymers for bovine albumin from Sigma (Lot No. 118H0594) analyzed in parallel. In contrast to $20 \%$ human albumin for therapeutic use, which must present a minimum amount of polymers (less than 5\%), as dictated by Resolution RDC-46 of May 18, 2000 of the Health Ministry of Brazil (18), the presence of these compounds in bovine albumin potentiates the reactions in hemagglutination tests, permitting a better visualization and interpretation of the results (6). In order to increase the polymer content in bovine serum albumin, a treatment with glutaraldehyde/formaldehyde was performed, with concentrations ranging from $0.02 / 0.00 \%$ to $0.08 / 0.15 \%$ and the preparation was heated in a water bath at $37^{\circ} \mathrm{C}$ for $12 \mathrm{~h}$. The best result was obtained with $0.06 \%$ glutaraldehyde and $0.10 \%$ formaldehyde. It was then possible to obtain on average $56.0 \%$ monomers, $23.6 \%$ dimers, $12.2 \%$ trimers, and 8.2 polymers, as analyzed by Superdex $200 \mathrm{HR}$ gel filtration and polyacrylamide gel electrophoresis (Figures 3 and 4, and Table 2). A mixture of glutaraldehyde and formaldehyde was used, since glutaraldehyde, by inducing the formation of polymers, also provokes an increase of the strong yellow color of albumin, whereas the presence of formaldehyde prevents the alteration of the normal color of albumin. This polymerized albumin did not present the phenomenon of rouleaux or nonspecific agglutination in hemagglutination tests. Titration tests with anti-Rho(D) serum using albumin with different degrees of polymerization were also performed, and the results were compared to those for the bovine albumin from Sigma. The albumin treated with $0.06 \%$ glutaraldehyde improved the agglutination with two additional titers in the dilution without causing interference (Table 3).

We conclude that the procedure described here yields a high-quality product of light yellow color similar to human albumin, which complies with requirements for diagnostic use.

\section{References}

1. Tanaka K (1987). Fracionamento de plasma bovino para isolamento da albumina e sua liofilização. Master's thesis, Faculdade de Ciências Farmacêuticas, USP, São Paulo, SP, Brazil.

2. Rochu D (1986). L'albumine humaine. Revue Française de Transfusion et ImmunoHematologie, 29: 13-33.

3. Murozuka T, Moriwara $M$, Ito $H$, Sekiguchi S, Naiki M, Tanaka K \& Aoyama T (1990). Bovine albumin, like protein in commercial human albumin for clinical use. Vox Sanguinis, 59: 1-5.

4. Sosler SD (1985). Enhancement media for transfusion testing. In: Ellisor SS \& Wallis
ME (Editors), Blood Bank Reagents: What to Use and When. American Association of Blood Banks, Arlington, VA,11-41.

5. J ones J M, Kekwich RA \& Goldsmith KLG (1969). Influence of polymers on the efficiency of serum albumin as a potentiator of incomplete Rh agglutinins. Nature, 224: 510-511.

6. Reckel RP \& Harris J (1978). The unique characteristics of covalently polymerized bovine serum albumin solutions when used as antibody detection media. Transfusion, 18: 397-406.

7. Pollack $W$, Hager HJ , Reckel R, Toren DA \& Singher HO (1965). A study of the forces involved in the second stage of hemagglutination. Transfusion, 5: 158183.

8. Curling J M (1983). Separation of plasma proteins. In: Curling J M (Editor), Pharmacia Fine Chemicals AB. Pharmacia, Uppsala, Sweden.

9. Cabrera-Crespo J (1998). Produção de albumina a partir de placentas humanas. Doctoral thesis, Instituto de Química, USP, São Paulo, SP, Brazil.

10. Cohn EJ, Strong LE, Hughes J r WL, Mulford DJ , Ashworth J N, Melin M \& Taylor HL (1946). Preparation and properties of serum and plasma proteins. IV. A sys- 
tem for the separation into fractions of the protein and lipoprotein components of biological tissues and fluids. J ournal of the American Chemical Society, 68: 459475.

11. Schneider W, Lefevre $\mathrm{H}$, Fiedler $\mathrm{H}$ \& McCarty LJ (1975). An altemative method of large scale, plasma fractionation for the isolation of serum albumin. Blut, 30: 121134.

12. Tanaka K, Sawatani E, Nakao H, Dias GA \& Arashiro F (1996). An alternative column chromatographic process for the production of human albumin. Brazilian J ournal of Medical and Biological Research, 29: 185-191.
13. Tanaka K, Shigueoka EM, Sawatani E, Dias GA, Arashiro F, Campos TCXB \& Nakao HC (1998). Purification of human albumin by the combination of the method of Cohn with liquid chromatography. Brazilian J ournal of Medical and Biological Research, 31: 1383-1388.

14. Yu MW \& Funlayson J S (1984). Stabilization of human albumin by caprylate and acetyltryptophanate. Vox Sanguinis, 47: 28-40.

15. King MJ (1987). Hemagglutination enhancement by bovine serum albumin is affected by octanoate, Reactive Blue 2 (Cibacron Blue), and polymer. Transfusion, 27: 302-308.
16. Grabar P \& Williams J r CA (1953). Immunoelectrophoresis. Biochimica et Biophysica Acta, 10: 193-200.

17. Wu H (1923). Studies on hemoglobin: UItra method for determination of hemoglobin as peroxidase. Biochemical J ournal, 2: 198-199.

18. Diário Oficial da União (19/05/2000). Ministério da Saúde, Agência Nacional da Vigilância Sanitária, Resolução RDC-46 de 18/05/2000.

19. Dunsford I \& Bowley CC (1967). Techniques in Blood Grouping. Vol. II. 2nd edn. Charles C. Thomas Publisher, Springfield, IL, 285-287. 